\title{
Recepcja Centesimus annus w nauczaniu społecznym papieży: Benedykta XVI i Franciszka
}

Encyklika Centesimus annus miała stanowić - w pewnym sensie - ponowne odczytanie Rerum novarum we współczesnej rzeczywistości'. Miała także w świetle społecznej troski Kościoła zobaczyć, ocenić oraz ukierunkować współczesną sytuację społeczno-gospodarczą i polityczną świataª ${ }^{2}$. Po rewolucji „Solidarności” i upadku muru berlińskiego chrześcijanie oraz wszyscy mieszkańcy globu stanęli wobec nowych problemów życia w świecie jeszcze do niedawna rozdzielonym pomiędzy dwa zwalczające się bloki ideologiczno-militarne i budowania chrześcijańskiego rozumienia dobra wspólnego realizowanego w nowych okolicznościach ${ }^{3}$. Właśnie to ukierunkowanie na przyszłość podkreślał Jan Paweł II, pisząc o wkraczaniu Kościoła w trzecie tysiąclecie dziejów ${ }^{4}$. Miało ono za fundament zadanie ewangelizacji, by poprzez szerzenie katolickiej nauki społecznej „objawić człowieka samemu sobie”s, dać świadectwo prawdy o człowieku, podając ramy antropologiczne konieczne także do budowania właściwego kształtu życia społecznego ${ }^{6}$. „Nauczanie społeczne należy do misji ewangelizacyjnej Kościoła w świecie i jako takie jest wyrazem jego nauczania zwyczajnego. Posiadając przede wszystkim przeznaczenie duszpasterskie,

1 CA 11.

J. Krucina, „Centesimus annus” jako relektura „Rerum novarum”, w: „Centesimus annus”. Tekst $i$ komentarze, red. F. Kampka, C. Ritter, Lublin 1998, s. 75.

3 R. Buttiglione, J. Merecki, Chrześcijaństwo jako podstawa wspólnego europejskiego domu, w: „Centesimus annus”. Tekst i komentarze, s. 99.

4 CA 62.

5 CA 54 .

${ }^{6}$ G. Weigel, „Centesimus annus a przyszłość demokracji: powtórna lektura, w: „Centesimus annus”. Tekst i komentarze, s. 115. 
rozwija doktrynę społeczną Kościoła w kontekście zmieniających się warunków historyczno-społecznych"”.

Podstawą dla takich wniosków był bardzo konkretny zapis Jana Pawła II w pamiętnej encyklice z 1991 roku: „Encyklikę Rerum novarum można uznać za ważny wkład w analizę społeczno-ekonomiczną końca xıx wieku, ale jej szczególna wartość wynika $\mathrm{z}$ faktu, że jest ona Dokumentem Urzędu Nauczycielskiego, a więc integralną częścią prowadzonego przez Kościół dzieła ewangelizacji, podobnie jak wiele innych Dokumentów tego rodzaju. Wynika stąd, że nauka społeczna ma sama w sobie wartość narzędzia ewangelizacji: jako taka głosi ona Boga i tajemnicę zbawienia w Chrystusie każdemu człowiekowi i z tej samej racji objawia człowieka samemu sobie. W tym świetle - i wyłącznie w tym - podejmuje inne zagadnienia, takie jak prawa każdego człowieka, a szczególnie "proletariatu», rodzina i wychowanie, powinności Państwa, ustrój społeczności narodowej i międzynarodowej, życie gospodarcze, kultura, wojna i pokój, szacunek dla życia od chwili poczęcia aż do śmierci”".

Po latach od publikacji encykliki Centesimus annus poszczególne myśli tego dokumentu - w tym ideę ewangelizacji - rozwijają i kontynuują papieże Franciszek i Benedykt xvi. Dlatego w niniejszym opracowaniu podjęto się próby uchwycenia recepcji wybranych idei przekazanych za pośrednictwem encykliki z 1991 roku przez następców Jana Pawła II. Posłużono się w tym celu przede wszystkim metodą analizy tekstów zastanych i syntezą prowadzącą do wniosków. Ponieważ encyklika Centesimus annus była dokumentem społecznym, w analizach wypowiedzi następców Jana Pawła II skupiono się na encyklikach społecznych: $\mathrm{Ca}$ ritas in veritate oraz Laudato si', oraz powiązanych z nimi tematycznie innych wypowiedziach następców św. Piotra. Zdecydowano się na zawężenie zakresu tematów oraz form wypowiedzi ze względu na ograniczoną możliwość prezentacji wyników badawczych oraz zogniskowano się przede wszystkim na wybranej kategorii źródeł nauczania społecznego - encyklice społecznej. Dla spójności metodologicznej wyodrębniono w encyklice Jana Pawła II wybrane wątki teoretyczne, których recepcji lub kontynuacji szukano w encyklikach społecznych kolejnych papieży:

\footnotetext{
A. Dylus, Zmienność i ciagłość. Polskie transformacje ustrojowe w horyzoncie etycznym, Warszawa 1997, s. 161.

8 CA 54.
} 
ewangelizacja jako klucz do zrozumienia społecznego nauczania Kościoła, antropologia, integralna wizja ekologii. Wyselekcjonowano te grupy zagadnień ze względu na usytuowanie w centralnym kluczu nauczania społecznego personalistycznej wizji człowieczeństwa i relacji społecznych, zrozumienia sensu społecznego nauczania Kościoła oraz umiejscowienia nauczania Kościoła na temat problemów ochrony środowiska i ekologii ludzkiej na trwałym fundamencie filozoficzno-teologicznym ${ }^{9}$.

Podstawowym założeniem badawczym jest hipoteza, iż Benedykt XVI i Franciszek rozwinęli główne idee encykliki papieża-Polaka w nowych warunkach społeczno-ekonomiczno-politycznych. W ten sposób dokonuje się rozwój i uwydatnia dynamika myśli społecznej Kościoła ${ }^{10}$. Jak pisał Franciszek Mazurek: „Są dwie cechy tego nauczania: ciągłość i stałość, i odnowa - rozwojowość. Nauczanie to jest stałe - constans gdyż pozostaje identyczne w swej najgłębszej inspiracji, w zasadach refleksji, kryteriach oceny i podstawowych wytycznych działania przede wszystkim z Ewangelią, która jest niezmienna, ale także niezmienna jest Tradycja. [...] Nauczanie społeczne Kościoła jest rozwojowe - dynamiczne - w podwójnym sensie: $\mathrm{z}$ depozytu wiary odczytywane są wciąż nowe treści; powstające zaś nowe kwestie społeczne wymagają nowych ocen i wytycznych działań" ${ }^{\prime 1}$.

\section{Nauczanie społeczne integralną częścią ewangelizacji}

Pierwszą ideą podjętą przez Jana Pawła II, a kontynuowaną przez jego następców jest rozwijanie katolickiej nauki społecznej jako wpisanej w misję ewangelizacyjną Kościoła. To zadanie ewangelizacyjnej misji Kościoła przypomniane we wprowadzeniu do tekstu - współcześnie na nowo rozwija papież Franciszek. W wyraźny sposób wypowiadał się na ten temat także Benedykt xvi. Społeczny sens ewangelizacji zakotwiczony jest w zadaniu wejścia w coraz pełniejszą komunię z Bogiem poszczególnych osób, a przez to zrealizowaniu się ich jako ludzi. Owo „uczłowieczanie”

\footnotetext{
9 P. de Plunkett, Ekologia - stereotypy i rzeczywistość. Od Biblii do naszych czasów, tłum. S. Filipowicz, Poznań 2008, s. 212-221.

${ }^{10}$ D. Tułowiecki, Społeczna doktryna katolicka, w: Encyklopedia katolicka, t. 18, Lublin 2013, k. 696-698.

${ }^{11}$ F. Mazurek, Katolicka nauka społeczna i jej status metodologiczny, w: Metodologiczne i teoretyczne problemy katolickiej nauki społecznej, red. P. Bortkiewicz, Poznań 2001, s. 24.
} 
ludzi i „uczłowieczanie” świata dokonuje się także na polu społecznym, gdy chrześcijanie, przyjmując ewangeliczną wizję życia, czynią świat bardziej ludzkim ${ }^{12} .3$ grudnia 2012 roku w swym przemówieniu do uczestników XXviI zgromadzenia plenarnego Papieskiej Rady „Iustitia et Pax” papież Benedykt Xvi - cytując Centesimus annus - powiedział: „Nauka społeczna, jak nas nauczał błogosławiony papież Jan Paweł II, jest integralną częścią ewangelizacyjnej misji Kościoła, i tym bardziej winna być uznawana za ważną w nowej ewangelizacji. Przyjmując Jezusa Chrystusa i Jego Ewangelię nie tylko w życiu osobistym, ale także w relacjach społecznych, stajemy się głosicielami wizji człowieka, jego godności, jego wolności i relacyjności, która jest naznaczona transcendencją w sensie zarówno horyzontalnym, jak i wertykalnym"13.

Natomiast Franciszek, wzywając Kościół do ewangelizacji, przypomniał - powołując się na Jana Pawła II - że wiara i odkupienie mają także znaczenie społeczne, ponieważ „Bóg w Chrystusie zbawia nie tylko pojedyncze osoby, ale również uzdrawia międzyludzkie stosunki społeczne" ${ }^{\prime 14}$. W innym zaś miejscu przypomniał - powołując się na Centesimus annus - skutki braku Ewangelii w życiu społecznym: alienację. „Niekiedy jesteśmy ludźmi twardego serca i umysłu, zapominamy się, bawimy się, zachwycamy się olbrzymimi możliwościami konsumpcji i rozrywki, jakie oferuje nam społeczeństwo. Dochodzi tu do pewnego rodzaju alienacji uderzającej w nas wszystkich, ponieważ «wyobcowane jest społeczeństwo, które poprzez formy społecznej organizacji, produkcji i konsumpcji utrudnia zarówno realizację tego daru, jak i budowanie tej międzyludzkiej solidarności»" ${ }^{\prime 15}$.

Myśl społeczna Kościoła - jako integralna część Jego ewangelizacyjnej misji - rozwija się na poszczególnych etapach dziejów i wobec przemian

${ }_{12}$ T. Borutka, Społeczne nauczanie Kościoła. Teoria i zastosowanie. Podręcznik do katolickiej nauki społecznej, Kraków 2008, s. 27; D. Wojtecki, Nauczanie społeczne Kościoła narzędziem ewangelizacji i promocji rodziny, http://civitaschristiana.pl/nauczanie-spoeczne-kocioa-narzdziem-ewangelizacji-i-promocji-rodziny (21.02.2016).

${ }^{13}$ Benedykt xvi, Przemówienie do uczestników zgromadzenia plenarnego Papieskiej Rady „Iustitia et Pax” (3 XII 2012), http://www.opoka.org.pl/biblioteka/W/w P/benedykt_ xvi/przemowienia/iustitia_03122012.html (12.03.2016).

${ }^{14}$ Franciszek, Adhortacja apostolska Ewangelii gaudium, 178.

15 Tamże, 196; por. CA 41. 
społecznych, zachowując swą ciągłość i dynamikę ${ }^{16}$. Także ewangelizacja i jej sposoby są zależne od czasów, w których przebiegają, problemów czy kwestii społecznych ${ }^{17}$. Podkreślona w Centesimus annus myśl o wpisaniu katolickiej nauki społecznej w misję ewangelizacyjną Kościoła, mimo zakończonego pontyfikatu jej autora, jest rozwijana i stanowi inspirację dla kolejnych następców św. Piotra. Skomplikowana sytuacja społeczno-ekonomiczna oraz rozwój nauk społecznych sprawiają, że w aplikacji Ewangelii do konkretnych warunków społecznych coraz bardziej wymagana jest współpraca z szerokim polem naukowców, a pełniący pasterską misję w Kościele, w tym sam papież, nie posiadają monopolu na interpretowanie rzeczywistości społecznej albo na składanie propozycji dla rozwiązania tych problemów ${ }^{18}$.

\section{Człowiek w centrum katolickiej myśli społecznej}

Jan Paweł II w encyklice z 1991 roku wskazał na priorytet człowieka w kształtowaniu życia społecznego, politycznego i gospodarczego: „W centrum całego dziedzictwa doktrynalnego Kościoła jest człowiek w swej konkretnej rzeczywistości grzesznika i sprawiedliwego"19. Myśl papieska ogniskuje się na teologicznym rozumieniu człowieka ${ }^{20}$ : człowieka pełnego, zintegrowanego, czyli zbawionego: „Kościół czerpie «zdolność rozumienia człowieka» z Bożego Objawienia. «Aby poznać człowieka, człowieka prawdziwego, człowieka integralnego, trzeba poznać Boga», powiedział Paweł vi, przywołując następnie słowa świętej Katarzyny ze Sieny, która wyrażała w modlitwie tę samą myśl: «W Twojej naturze,

${ }^{16} \mathrm{~J}$. Mazur, Afirmacja dobra wspólnego. Katolicka nauka społeczna propozycja dla polityki, Toruń 2015, s. 16; H. Juros, Spór o metodologię nauki społecznej Kościoła, w: „Centesimus annus". Tekst $i$ komentarze, s. 349-352.

${ }^{17}$ D. Tułowiecki, Pomiędzy „wolnościa od religii” a „renesansem religijności” - zmiany społeczne jako przestrzeń i uwarunkowania działalności ewangelizacyjnej Kościoła, w: Mała ojczyzna. Zachowanie dziedzictwa kulturowego ziemi piątnickiej, red. D. Tułowiecki, Sz. Dobecki, Piątnica-Łomża 2015, s. 88.

${ }_{18}$ J. Mazur, Afirmacja dobra wspólnego..., s. 21.

${ }^{19}$ CA 53.

${ }^{20} \mathrm{~J}$. Mazur, Persona in societate. Wybrane zagadnienia chrześcijańskiej nauki o człowieku, Kraków 2014, s. 70-72; tenże, Od kerygmatu do Ewangelii życia. Dzieje katolickiej myśli społecznej w zarysie, Radom 2003, s. 229. 
wieczne Bóstwo, poznam moją naturę»" ${ }^{21}$. Brak właściwej antropologii papież uznał za główną przyczynę upadku komunizmu, który dokonał głębokich zniszczeń nie tyle w sektorze ekonomiczno-gospodarczym, co we wnętrzu człowieka ${ }^{22}$. Ideologia komunistyczna narzucała w sposób polityczny ateistyczną wizję człowieka i społeczeństwa. Ateizm jednak był postrzegany przez Jana Pawła II jako zagrożenie dla człowieka, utrudniające zrozumienie pełni ludzkiej tożsamości. Taki wniosek nasuwa się, gdy czyta się w Centesimus annus, że „tylko wiara jednak objawia $\mathrm{mu}$ [człowiekowi] w pełni jego prawdziwą tożsamość” ${ }^{23}$.

Błędna, ateistyczna antropologia, realizowana w sposób polityczno-kulturowy, fałszowała wolność i prawdę, bez których nie ma człowieczeństwa ${ }^{24}$. Te deformacje i okaleczenia antropologiczne $z$ jednej strony rodziły pustkę i „niespełnienie” w człowieczeństwie tych, którzy jej ulegali, z drugiej - dawała siły do świadectwa tym, którzy mimo nachalnej propagandy, prześladowań i przemocy pozostawali wierni Bogu: „Prawdziwą jednakże przyczyną tych «rzeczy nowych» jest pustka duchowa wytworzona przez ateizm, który pozostawił młode pokolenia bez drogowskazów, a nierzadko doprowadzał do tego, iż w nieustannym poszukiwaniu własnej tożsamości i sensu życia odkrywały one na nowo religijne korzenie kultury swych narodów oraz samą osobę Chrystusa, jako adekwatną egzystencjalnie odpowiedź na pragnienie dobra, prawdy i życia, obecne w sercu każdego człowieka. Poszukiwanie to czerpało energię ze świadectwa ludzi, którzy w trudnych warunkach i pośród prześladowań pozostali wierni Bogu. Marksizm zapowiadał, że wykorzeni potrzebę Boga z serca człowieka, ale rzeczywistość dowiodła, że nie da się tego dokonać, nie zadając gwałtu ludzkiemu sercu"25.

Idea, wedle której człowiek realizuje się w pełni wyłącznie w Bożej perspektywie i żyjąc w komunii z Bogiem, jest kontynuowana w nauczaniu następców Jana Pawła II. Benedykt xvi przypomniał o tym, ogłaszając Rok Wiary oraz motywując wszystkich katolików, by w ich

${ }^{21}$ CA 55.

${ }^{22}$ J. Mazur, Katolicka nauka społeczna. Skrypt dla studentów teologii, Kraków 1992, s. 155.

${ }^{23}$ CA 54 .

${ }^{24}$ M. Zięba, Papieże i kapitalizm. Od „Rerum novarum” po „Centesimus annus”, Kraków 1998, s. 171.

${ }^{25}$ CA 24. 
centrum życia była zawsze Bóg w Jezusie Chrystusie ${ }^{26}$. W Caritas in veritate przypomniał, że zadaniem Kościoła jest troska o „promocję człowieka” i prawdziwych relacji międzyludzkich - braterstwa: „cały Kościół, w całym swoim istnieniu i działaniu, podczas gdy głosi, celebruje i działa w miłości, pragnie promować integralny rozwój człowieka" ${ }^{\text {27 }}$. Bez wiary i wymiaru religijnego zostaje bowiem zakłócona wewnętrzna harmonia świata ludzkiego, rozwój osoby i całej ludzkości: „autentyczny rozwój człowieka obejmuje całą osobę we wszystkich jej wymiarach. Bez perspektywy życia wiecznego, postępowi ludzkiemu na tym świecie brakuje horyzontu. Zamknięty w granicach historii, z łatwością może zostać sprowadzony do tego tylko, by zwiększać stan posiadania. [...] Rozwój ów wymaga $[\ldots]$ transcendentnej wizji osoby, potrzebuje Boga: bez Niego albo odbiera się prawo do rozwoju, albo składa się go jedynie w ręce człowieka, który popadł w przekonanie o samo-zbawieniu i w efekcie opowiada się za rozwojem odczłowieczonym. Z drugiej strony, dzięki spotkaniu z Bogiem potrafimy nie tylko nie «widzieć w innym człowieku zawsze jedynie innego», lecz rozpoznać w nim obraz Boży, dochodząc tym samym do prawdziwego odkrycia innego człowieka i do dojrzałej miłości, która «staje się troską o człowieka i posługą dla drugiego»"28.

Benedykt XVI także zauważa zagrożenia wynikające $z$ ateizmu. Nie jest on, jak w warunkach „żelaznej kurtyny”, narzucony na drodze procedur państwa komunistycznego, lecz propagowany przez różne typy umysłowości: „Według tego modelu myślenia, który ma się za naukowy, sprawy wiary jawą się jako archaiczne, mityczne, przynależne do dawnej cywilizacji. Religia, w każdym razie chrześcijańska, uważana jest za relikt przeszłości”29. Jednak odrzucenie antropologii opartej na biblijnej wizji człowieczeństwa „nieodwracalnie prowadzi do błędnych interpretacji [człowieka] i chybionych decyzji” ${ }^{30}$. To porzucenie Boga zniekształca

${ }^{26}$ D. Tułowiecki, Wiara jako klucz do tożsamości kapłańskiej. Próba komentarza w świetle Dekretu o postudze i życiu prezbiterów „Presbyterorum ordinis”, „Studia Paradyskie” 23 (2013), s. 157.

${ }_{27}$ Benedykt Xvi, Encyklika Caritas in veritate, 11.

${ }^{28}$ Tamże.

${ }^{29}$ Benedykt XVI w rozmowie z P. Seewaldem, Światłość świata. Papiez, Kościół i znaki czasu, tłum. P. Napiwodzki, Kraków 2011, s. 144.

${ }^{30}$ N. Neuhaus, H. Langes, Wokół wartości chrześcijańskiej demokracji, tłum. M. Wiatr, Gliwice 2012, s. 40. 
relacje międzyludzkie oraz jakość życia społecznego. Bez uzasadnienia w wierze - zdaniem Benedykta XVI - niemożliwa jest pełna relacja braterstwa między ludźmi i między narodami. Nikt i nic, poza Bogiem, nie uzdalnia ludzi i nie motywuje, by patrzyli i traktowali się jak bracia: „Zacofanie w rozwoju ma przyczynę poważniejszą niż luki w myśleniu: to «brak braterstwa między ludźmi i między narodami». Czy ludzie o własnych siłach mogą dojść do braterstwa? Społeczeństwo coraz bardziej zglobalizowane zbliża nas, ale nie czyni nas braćmi. Rozum sam potrafi pojąć, że ludzie są równi i dać podstawę ich obywatelskiemu współżyciu, ale nie potrafi zaprowadzić braterstwa. Ma ono początek w transcendentnym powołaniu Boga Ojca, który jako pierwszy nas umiłował, ucząc nas przez swego Syna, czym jest miłość braterska. Paweł vi, ukazując różne poziomy składające się na proces rozwoju człowieka, obok wiary stawiał na ich szczycie «jedność wszystkich w miłości Chrystusa, który nas wzywa, abyśmy jako synowie uczestniczyli w życiu Boga żywego, Ojca wszystkich ludzi»" ${ }^{31}$.

Według encykliki Lumen fidei, niejako łączącej pontyfikaty Benedykta XVI i Franciszka, wiara jest światłem do zrozumienia człowieka i życia społecznego ${ }^{32}$. Stanowi ona źródło szczęścia ${ }^{33}$, bo daje boże życie, nowe doświadczenie i „pełną blasku wizję życia” ${ }^{34}$. Człowiek jest w swej istocie zadaniem Franciszka - przeznaczony do dialogu i komunii z Bogiem. Wówczas staje się w pełni sobą i osiąga szczęście ${ }^{35}$. Tymczasem eliminowanie Ewangelii z życia, z kultury, z polityki i zasad ekonomicznych wprowadza antropologiczny chaos i pozbawia społeczności autentycznych i głębokich więzi ${ }^{36}$. W wersji skrajnej odejście od Boga, a ukierunkowanie na egoizm tworzy „cywilizację obojętności”, którą przełamać

${ }^{31}$ Benedykt Xvi, Encyklika Caritas in veritate, 19.

${ }^{32}$ Franciszek, Encyklika Lumen fidei, 4.

${ }_{33}$ R. Nęcek, Od kapłaństwa do społeczeństwa. Wybrane kwestie z nauki społecznej papieża Franciszka, Kraków 2014, s. 47.

${ }^{34}$ Franciszek, Encyklika Lumen fidei, 5.

${ }_{35}$ D. Tułowiecki, Dialogue and the "culture of encounter" as the path to the peace in the modern world (in the light of Pope Francis course), „Українське релігієзнавство” (2015), nr 74/74, s. 108-109.

${ }^{36}$ D. Fares, Papież Franciszek o kulturze spotkania, tłum. S. Tuszyńki, Kraków 2014, s. 38-39. 
może wyłącznie motywowana wiarą „kultura spotkania” ${ }^{37}$. Wiara daje nowe spojrzenie na samego siebie, na relacje międzyludzkie, na ludzkość, a nawet całe stworzenie, tak, iż ze wszystkich tworzy „rodzaj uniwersalnej rodziny, wspaniałej komunii pobudzającej do świętego, serdecznego i pokornego szacunku"38.

Perspektywa wiary daje, zdaniem papieża Franciszka, także nowe spojrzenie na dobro wspólne oraz umożliwia realizację zasady powszechnego przeznaczenia dóbr. Wynika to z przekonania papieża, iż postawa wiary nosi w sobie głębokie pragnienie przemiany świata $\mathrm{i}$ wejścia $\mathrm{w}$ relacje z ludzkościąa ${ }^{39}$. Dlatego pisze on w encyklice o wierze: „Właśnie dzięki powiązaniu z miłością (por. Ga 5,6) światło wiary konkretnie służy sprawiedliwości, poszanowaniu praw i pokojowi. Wiara rodzi się ze spotkania z pierwotną miłością Bożą, w którym ukazuje się sens i dobroć naszego życia. Zostaje ono oświecone w takiej mierze, w jakiej włącza się w dynamikę zapoczątkowaną przez tę miłość, to znaczy, gdy staje się drogą zmierzającą do pełni miłości i jej praktykowaniem. Światło wiary jest w stanie uwydatnić bogactwo ludzkich relacji, to, że mogą trwać, być wiarygodne, ubogacać wspólne życie. Wiara nie oddala od świata i nie jest czymś oderwanym od konkretnego zaangażowania współczesnych ludzi. Bez wiarygodnej miłości nie byłoby niczego, co sprawia, że ludzie prawdziwie są zjednoczeni. Jedność między nimi byłaby do pomyślenia jedynie jako oparta na użyteczności, wspólnych interesach, lęku, ale nie na dobru wspólnego życia czy na radości, jaką może budzić po prostu obecność drugiego człowieka. Wiara pozwala zrozumieć architekturę relacji ludzkich, ponieważ dostrzega ich głęboki fundament i ostateczne przeznaczenie w Bogu, i w Jego miłości, dzięki temu oświeca sztukę budowania, służąc dobru wspólnemu. Tak, wiara jest dobrem dla wszystkich, jest dobrem wspólnym, jej światło nie oświeca tylko wnętrza Kościoła i nie służy jedynie budowaniu wiecznego miasta w zaświatach. Pomaga nam ona budować nasze społeczności, tak by zmierzały ku przyszłości dającej nadzieję" ${ }^{40}$.

${ }^{37}$ D. Tułowiecki, Dialogue and the „culture of encounter”..., s. 109-118.

${ }^{38}$ LS 89.

${ }^{39}$ J. Mazur, Afirmacja dobra wspólnego..., s. 96.

${ }^{40}$ Franciszek, Encyklika Lumen fidei, 51. 


\section{Chrześcijańska wizja ochrony harmonii stworzeń}

W ideę antropologiczną oraz dobra wspólnego wpisuje się troska o ochronę środowiska. Współczesna deformacja antropologiczna, wedle której człowiek bardziej kieruje sie żądzą posiadania niż poszukiwaniem prawdy, oraz „wyzwolenie" z etyki i estetyki rodzą postawy, które nie generują zachwytu dla istnienia, piękna, a także nie pozwalają odczytywać w rzeczach widzialnych przesłania niewidzialnego Boga-Stwórcy. Wedle Jana Pawła II relacja człowieka do stworzeń oraz Boga-Stwórcy pozwala odkryć głębię człowieczeństwa wraz z majestatem i dobrocią Boga. Kontakt z przyrodą, w tym: rekreacja, odczuwanie pokoju oraz pogody ducha, które są dostępne na drodze kontemplacji piękna, stają sie drogą wychowania i doskonalenia człowieczeństwa. Konieczne dla niej jest jednak utrzymanie zdrowego środowiska naturalnego ${ }^{41}$.

„U korzeni bezmyślnego niszczenia środowiska naturalnego tkwi błąd antropologiczny, niestety rozpowszechniony w naszych czasach. Człowiek, który odkrywa swą zdolność przekształcania i w pewnym sensie stwarzania świata własną pracą, zapomina, że zawsze dzieje się to w oparciu o pierwszy dar, otrzymany od Boga na początku w postaci rzeczy przezeń stworzonych. Człowiek mniema, że samowolnie może rozporządzać ziemią, podporządkowując ją bezwzględnie własnej woli, tak jakby nie miała ona własnego kształtu i wcześniejszego, wyznaczonego jej przez Boga, przeznaczenia, które człowiek, owszem, może rozwijać, lecz któremu nie może się sprzeniewierzać. Zamiast pełnić rolę współpracownika Boga w dziele stworzenia, człowiek zajmuje Jego miejsce i w końcu prowokuje bunt natury, raczej przez niego tyranizowanej, niż rządzonej”"

Obok ekologii przyrodniczej Jan Paweł II przypomina również o koniecznej trosce o ekologię ludzką. „Podstawę ekologii ludzkiej stanowi godność osoby ludzkiej, jej ukierunkowanie na dążenie do prawdy i dobra oraz zdolność nawiązywania osobowych relacji. [...] W zakres tego terminu wchodzą więzi międzyludzkie i wspólnoty ludzkie oraz podstawowe struktury życia społecznego, które mają tworzyć podstawowe środowisko

${ }^{41}$ J. Mariański, Problem ochrony środowiska i „ekologii ludzkiej”, w: „Centesimus annus”. Tekst $i$ komentarze, s. 327-328.

${ }^{42}$ CA 37. 
ludzkie”43. Pisał Jan Paweł II w 1991 roku: „Nie tylko ziemia została dana człowiekowi przez Boga, aby używał jej z poszanowaniem pierwotnie zamierzonego dobra, dla którego została mu ona dana, ale również człowiek jest dla siebie samego darem otrzymanym od Boga i dlatego musi respektować naturalną i moralną strukturę, w jaką został wyposażony" ${ }^{34}$. Dlatego chrześcijanie mają obowiązek - wedle kompetencji i zdolności - udziału w budowie społeczeństwa na miarę człowieka. Są także wewnętrznie zobowiązani do unikania rozbijania więzi społecznych i niszczenia harmonii stosunków międzyludzkich ${ }^{45}$. Autentyczna ekologia w ujęciu integralnym jest zadaniem chrześcijanina. Bowiem istnienie świata z zaburzonymi relacjami międzyludzkimi i niszczonym środowiskiem naturalnym stanowi zagrożenie dla człowieka i jego autentycznego dobra. Utrwalenie tych zagrożeń, które utrudniają lub uniemożliwiają życie ludzi w prawdzie, „mogą tworzyć specyficzne struktury grzechu, przeszkadzając w pełnej ludzkiej realizacji tym, którzy są przez te struktury w rozmaity sposób uciskani. Burzenie takich struktur i zastępowanie ich bardziej autentycznymi formami współżycia jest zadaniem wymagającym odwagi i cierpliwości”"46.

Ideę integralnej ekologii kontynuowali następcy autora Centesimus annus. Benedykt XVI poświęcił integralnemu ujęciu ekologii fragmenty w Caritas in veritate oraz katechcezy i przemówienia. „Ziemia jest cennym darem Stwórcy - mówił 2 września 2009 roku - który zaplanował jej właściwy porządek [...]"47. Do szerokiego, teologicznego spojrzenia na dzieło stworzenia wezwał także, przemawiając w parlamencie niemieckim, gdy mówił: „Trzeba na nowo otworzyć szeroko okna, winniśmy na nowo ujrzeć rozległość świata, niebo i ziemię, oraz nauczyć się korzystać z tego wszystkiego w sposób sprawiedliwy”"48. To „szerokie

${ }^{43}$ K. Jeżyna, Ekologia ludzka, w: Ekologia. Przesłanie moralne Kościoła, red. J. Nagórny, J. Gocko, Lublin 2002, s. 107.

${ }^{44}$ CA 38.

${ }^{45}$ J. Mariański, Troska Kościoła o ochronę środowiska, w: Katolicka nauka społeczna. Podstawowe zagadnienia z życia gospodarczego, red. J. Kupny, S. Fel, Katowice 2003, s. 211.

${ }^{46}$ CA 38.

${ }^{47}$ Benedykt XVI, Ziemia jest cennym darem Stwórcy (katecheza z 2 IX 2009), http://papiez.wiara.pl/doc/379323.Ziemia-jest-cennym-darem-Stworcy (12.03.2016).

${ }^{48}$ Benedykt xvi, Przemówienie w Bundestagu (22 IX 2011), http://www.opoka.org.pl/ biblioteka/W/wP/benedykt_xvi/przemowienia/niemcy2011_bundestag_22092011.html (12.03.2016). 
spojrzenie" to perspektywa ekologii integralnej, łączącej ekologię przyrody i ekologię ludzką. Troska ta jest warunkiem „integralnego rozwoju”, spojrzenie na świat, jako dzieło Stwórcy, wewnętrznie motywuje do troski oraz daje perspektywę odpowiedzialności za naturę wobec następnych pokoleń ${ }^{49}$. Benedykt xvi przypominał także konieczność ochrony ekologii ludzkiej - w duchu św. Franciszka oraz porządku relacji społecznych - w kluczu braterstwa: „Poszanowanie dzieła stworzenia ma wielką wagę, ponieważ «stworzenie jest początkiem i podstawą wszystkich dzieł Bożych», a jego ochrona nabiera dziś zasadniczego znaczenia dla pokojowego współżycia ludzkości. Jeśli bowiem ludzkie okrucieństwo wobec drugiego jest źródłem wielu niebezpieczeństw, które zagrażają pokojowi i autentycznemu, integralnemu rozwojowi człowieka: wojen, międzynarodowych i regionalnych konfliktów, zamachów terrorystycznych i pogwałceń praw ludzkich, to nie mniej niepokojące są zagrożenia, jakie rodzi lekceważenie - jeśli nie wręcz nadużywanie - ziemi i bogactw naturalnych, które są darami Boga. Dlatego konieczne jest odnowienie i umocnienie przez ludzkość «przymierza między człowiekiem a środowiskiem, mającego odzwierciedlać stwórczą miłość Boga, od którego pochodzimy i ku któremu zdążamy»" ".

Natomiast papież Franciszek odpowiedzialności za stworzenie poświęcił całą encyklikę społeczną Laudato si' z 2015 roku. Podkreślił w niej konieczność moralnej oceny ochrony środowiska, oceny zła wyrządzanego naturze i innym ludziom oraz zagrożeń ekologii ludzkiej. „[Ziemia, nasza] siostra protestuje z powodu zła, jakie jej wyrządzamy nieodpowiedzialnym wykorzystywaniem i rabunkową eksploatacją dóbr, które Bóg w niej umieścił. Dorastaliśmy myśląc, że jesteśmy jej właścicielami i rządcami uprawnionymi do jej ograbienia. Przemoc, jaka istnieje w ludzkich sercach zranionych grzechem, wyraża się również w objawach choroby, jaką dostrzegamy w glebie, wodzie, powietrzu i w istotach żywych. $Z$ tego względu wśród najbardziej zaniedbanych i źle traktowanych znajduje się nasza uciskana i zdewastowana ziemia, która «jęczy i wzdycha w bólach rodzenia» $(\mathrm{Rz} 8,22){ }^{\prime 5}$.

\footnotetext{
${ }^{49}$ Benedykt XVI, Encyklika Caritas in veritate, 48.

5o Benedykt XVI, Jeśli chcesz krzewić pokój, strzeż dzieła stworzenia. Orędzie na Światowy Dzień Pokoju 1 stycznia 2010.

${ }^{51}$ LS 2.
} 
Papież, który ustanowił Światowy Dzień Modlitwy o Ochronę Stworzenia na dzień 1 września, stale przypomina światu o konieczności ochrony naturalnych relacji międzyludzkich oraz zagrożeniach ekologii ludzkiej. $\mathrm{Na}$ tym polu widzi bowiem wiele niebezpieczeństw, przyczynę obaw definiując jako „głęboką" zarówno na polu ekonomii, antropologii, jak i etyki. Jako zagrożenia ekologii ludzkiej uznaje: kult pieniądza, bożka zysku, konsumpcjonizm, kulturę odrzucenia, marnotrawstwo żywności, zanik solidarności ${ }^{52}$. Wedle papieża drogą przywracania właściwych relacji społecznych są: kultura dialogu ${ }^{53}$, nawrócenie, przełamanie obojętności, przyzwyczajenia i cynizmu, współczucie, zrównoważony rozwój ${ }^{54}$, rozwój i promocja nowych, ekologicznych stylów życia ${ }^{55}$.

\section{Próba podsumowania}

Nauczanie - w tym nauczanie społeczne - Jana Pawła II stanowi ogromny wkład w budowanie myśli społecznej Kościoła. Stanowi ono swoiste i arcybogate dziedzictwo ${ }^{56}$, które - jak wykazała powyższa analiza - jest podejmowane i rozwijane przez następców świętego papieża z Polski. Dokonując, chociażby takiej jak ta, skrótowej i ukierunkowanej analizy wypowiedzi następców Jana Pawła II, można stwierdzić, że myśli przez niego formułowane, na przykład w encyklice Centesimus annus, są podejmowane i rozwijane przez kolejnych następców św. Piotra. Zarówno Benedykt XVI, jak i Franciszek dokonywali, a Franciszek nadal aktywnie dokonuje wnikliwej analizy rzeczywistości społecznej oraz dylematów, przed którymi stają ludzie wiary. Obaj, tak jak Jan Paweł II, nie tracą z oczu problemów społecznych świata, które nierozwiązywane lub roz-

${ }^{52}$ Franciszek, Pilnie potrzebna ekologia (katecheza z 5 VI 2013), http://www.swietyjozef. kalisz.pl/RokWiary/39.html (12.03.2016).

${ }_{53} \mathrm{D}$. Tułowiecki, The "culture of encounter" as a way to prevent and resolve conflicts in the modern world (in the light of the teaching of Pope Francis course), w: Религия и/или повседневность, ред. С. И. Шатравский, М. В. Казмирук, Минск 2015, s. 403-410.

${ }^{54}$ Franciszek, Przezwycięż obojętność i zyskaj pokój. Orędzie na Światowy Dzień Pokoju 1 stycznia 2016.

${ }_{55}$ LS 203-208.

${ }^{56}$ D. Tułowiecki, Nauczanie Jana Pawła II - dziedzictwo czy balast? Próba szkicu socjologicznego, w: Geniusz błogosławionego Jana Pawła II, red. P. Artemiuk, J. Kotowski, Łomża 2011, s. 146-151. 
wiązywane z pominięciem zasad molarnych niszczą ludzkość, zagrażają środowisku naturalnemu oraz generują nowe, coraz bardziej skomplikowane trudności dla społeczności globalnej.

Wyszczególnione powyżej zagadnienia należą do tych kwestii, które bezpośrednio dotyczą człowieka, istoty posłannictwa Kościoła w świecie oraz społeczności globalnej. Te trzy grupy tematów zostały wybrane $\mathrm{w}$ ten sposób, by można było okazać recepcję kluczowych - w opinii autora - nurtów nauczania Centesimus annus. Autor zakłada, ze inni badacze i analitycy być może wyselekcjonowaliby odrębne motywy oraz odmiennie usytuowali pole badawcze. Taka różnorodność spojrzeń oraz odmienność selekcji otwiera nowe przestrzenie analiz i rozszerza przestrzenie wniosków, ukazując równocześnie wielkość myśli Jana Pawła II oraz trudność zawężonych analiz.

Myśl społeczna - w tym myśl Jana Pawła II, stanowi dla Kościoła wciąż skarbiec natchnień i bogactwo materiału badawczego. Wracają do niego kolejni papieże, tworzący Nauczycielski Urząd Kościoła, poszczególni biskupi, naukowcy, wierzący i niewierzący. Także ostatnia encyklika społeczna z 1991 roku jest cennym dokumentem, wartym stałych analiz. W jej świetle można i należy szukać sposobów analizy współczesnej rzeczywistości - jak to robił Jan Paweł II - wedle klucza: widzieć, oceniać, działać. Dokumenty Jana Pawła II mogą bowiem stanowić metodologiczny wzorzec obiektywizmu i szerokiego spojrzenia w „widzieć”, trafności w „oceniać” oraz rozsądku i umiarkowania w „działać”. Dlatego należy mniemać, że wielu autorów, mimo upływu czasu, będzie analizować dzieła papieża z Polski, a wierzący i niewierzący - traktować jego głos jako ważne wypowiedzi na temat sytuacji człowieka, świata i Kościoła w świecie.

\section{Bibliografia}

Benedykt xvi, Encyklika Caritas in veritate, przedruk: Libreria Editrice Vaticana, Wydawnictwo M, Kraków 2009.

Benedykt Xvi, Jeśli chcesz krzewićpokój, strzeż dzieła stworzenia. Orędzie na Światowy Dzień Pokoju 1 stycznia 2010, http://www.opoka.org.pl/biblioteka/W/ wP/benedykt_xvi/przemowienia/pokoj2010_lev_08122009.html (12.03.2016). Benedykt XVI, Przemówienie do uczestników zgromadzenia plenarnego Papieskiej Rady „Iustitia et Pax” (3 XII 2012), http://www.opoka.org.pl/biblioteka/W/wP/ benedykt_xvi/przemowienia/iustitia_03122012.html (12.03.2016). 
Benedykt xvi, Przemówienie w Bundestagu (22 Ix 2011), http://www.opoka. org.pl/biblioteka/W/wP/benedykt_xvi/przemowienia/niemcy2011_bundestag_22092011.html (12.03.2016).

Benedykt XVI, Ziemia jest cennym darem Stwórcy (katecheza z 2 IX 2009), http:// papiez.wiara.pl/doc/379323.Ziemia-jest-cennym-darem-Stworcy (12.03.2016). Borutka T., Społeczne nauczanie Kościoła. Teoria i zastosowanie. Podręcznik do katolickiej nauki społecznej, Kraków 2008.

Buttiglione R., Merecki J., Chrześcijaństwo jako podstawa wspólnego europejskiego domu, w: „Centesimus annus”. Tekst i komentarze, red. F. Kampka, C. Ritter, Lublin 1998, s. 99-114.

Dylus A., Zmienność i ciagłość. Polskie transformacje ustrojowe w horyzoncie etycznym, Warszawa 1997.

Fares D., Papież Franciszek o kulturze spotkania, tłum. S. Tuszyńki, Kraków 2014.

Franciszek, Adhortacja apostolska Ewangelii gaudium, przedruk: Libreria Editrice Vaticana, Wydawnictwo M, Kraków 2013.

Franciszek, Encyklika Laudato si', Libreria Editrice Vaticana, Watykan 2015.

Franciszek, Encyklika Lumen fidei, przedruk: Libreria Editrice Vaticana, Wydawnictwo M, Kraków 2013.

Franciszek, Pilnie potrzebna ekologia (katecheza z 5 VI 2013), http://www.swietyjozef.kalisz.pl/RokWiary/39.html (12.03.2016).

Franciszek, Przezwycięż obojętność i zyskaj pokój. Orędzie na Światowy Dzień Pokoju 1 stycznia 2016, Libreria Editrice Vaticana, Watykan 2015.

Jan Paweł II, Encyklika Centesimus annus, przedruk: Libreria Editrice Vaticana, Włocławek 1991.

Jeżyna K., Ekologia ludzka, w: Ekologia. Przesłanie moralne Kościoła, red. J. Nagórny, J. Gocko, Lublin 2002, s. 105-138.

Juros H., Spór o metodologię nauki społecznej Kościoła, w: „Centesimus annus”. Tekst $i$ komentarze, red. F. Kampka, C. Ritter, Lublin 1998, s. 349-372.

Krucina J., „Centesimus annus” jako relektura „Rerum novarum”, w: „Centesimus annus". Tekst i komentarze, red. F. Kampka, C. Ritter, Lublin 1998, s. 75-88.

Mariański J., Problem ochrony środowiska $i$ „ekologii ludzkiej”, w: „Centesimus annus”. Tekst i komentarze, red. F. Kampka, C. Ritter, Lublin 1998, s. 325-339.

Mariański J., Troska Kościoła o ochronę środowiska, w: Katolicka nauka społeczna. Podstawowe zagadnienia z życia gospodarczego, red. J. Kupny, S. Fel, Katowice 2003, s. 202-218.

Mazur J., Afirmacja dobra wspólnego. Katolicka nauka społeczna propozycja dla polityki, Toruń 2015. 
Mazur J., Katolicka nauka społeczna. Skrypt dla studentów teologii, Kraków 1992. Mazur J., Od kerygmatu do Ewangelii życia. Dzieje katolickiej myśli społecznej $w$ zarysie, Radom 2003.

Mazur J., Persona in societate. Wybrane zagadnienia chrześcijańskiej nauki o człowieku, Kraków 2014.

Mazurek F., Katolicka nauka społeczna i jej status metodologiczny, w: Metodologiczne i teoretyczne problemy katolickiej nauki społecznej, red. P. Bortkiewicz, Poznań 2001, s. 21-35.

Neuhaus N., Langes H., Wokół wartości chrześcijańskiej demokracji, tłum. M. Wiatr, Gliwice 2012.

Nęcek R., Od kapłaństwa do społeczeństwa. Wybrane kwestie z nauki społecznej papieża Franciszka, Kraków 2014.

Plunkett P. de, Ekologia - stereotypy i rzeczywistość. Od Biblii do naszych czasów, tłum. S. Filipowicz, Poznań 2008.

Światłość świata. Papież, Kościół i znaki czasu (Benedykt xvi w rozmowie z P. Seewaldem), tłum. P. Napiwodzki, Kraków 2011.

Tułowiecki D., Dialogue and the „culture of encounter” as the path to the peace in the modern world (in the light of Pope Francis course), „Українське релігієзнавство” (2015), nr 74/74, s. 90-119.

Tułowiecki D., Nauczanie Jana Pawła II - dziedzictwo czy balast? Próba szkicu socjologicznego, w: Geniusz błogosławionego Jana Pawła II, red. P. Artemiuk, J. Kotowski, Łomża 2011, s. 99-152.

Tułowiecki D., Pomiędzy „wolnością od religii” a „renesansem religijności” - zmiany społeczne jako przestrzeń i uwarunkowania działalności ewangelizacyjnej Kościoła, w: Mała ojczyzna. Zachowanie dziedzictwa kulturowego ziemi piątnickiej, red. D. Tułowiecki, Sz. Dobecki, Piątnica-Łomża 2015, s. 87-159.

Tułowiecki D., Społeczna doktryna katolicka, w: Encyklopedia katolicka, t. 18, Lublin 2013, k. 696-698.

Tułowiecki D., The „culture of encounter” as a way to prevent and resolve conflicts in the modern world (in the light of the teaching of Pope Francis course), $\mathrm{w}$ : Религия и/или повседневность, ред. С. И. Шатравский, М. В. Казмирук, Минск 2015, s. 403-410.

Tułowiecki D., Wiara jako klucz do tożsamości kapłańskiej. Próba komentarza w świetle Dekretu o posłudze i życiu prezbiterów „Presbyterorum ordinis”, „Studia Paradyskie" 23 (2013), s. 157-191.

Weigel G., „Centesimus annus” a przyszłość demokracji: powtórna lektura, w: „Centesimus annus”. Tekst i komentarze, red. F. Kampka, C. Ritter, Lublin 1998, s. 115-131. 
Wojtecki D., Nauczanie społeczne Kościoła narzędziem ewangelizacji i promocji rodziny, http://civitaschristiana.pl/nauczanie-spoeczne-kocioa-narzdziem-ewangelizacji-i-promocji-rodziny (21.02.2016).

Zięba M., Papieże i kapitalizm. Od "Rerum novarum” po „Centesimus annus”, Kraków 1998.

\begin{abstract}
Abstrakt
W roku 1991 Jan Paweł II napisał encyklikę Centesimus annus, w której poddał ocenie moralnej problemy społeczne końca xx wieku. Encyklika ta stanowi ważną cześć społecznego nauczania Kościoła. Główne idee tej encykliki kontynuowali Benedykt xvı i Franciszek. Papieże ci w swym nauczaniu rozwinęli następujące zagadnienia: usytuowanie nauczania społecznego Kościoła w zadaniu ewangelizacji, koncepcja człowieczeństwa, zagadnienie ekologii.
\end{abstract}

Reception Centesimus annus in the social teaching of the popes Benedict Xvi and Francis

\begin{abstract}
In 1991, John Paul II wrote the encyclical Centesimus annus. The Pope evaluated the social problems of the late twentieth century. This encyclical is an important part of the social teaching of the Church. The main ideas of Centesimus annus are continued and developed by Benedict XVI and Francis. The Popes developed the following issues: evangelization, the concept of humanity and the problem of ecology.
\end{abstract}

